\title{
Growth Hormone Determination in Children Using an Immunofunctional Assay in Comparison to Conventional Assays
}

\author{
Simone Stark ${ }^{a, c}$ Rolf Peter Willig ${ }^{b, c}$ \\ ${ }^{a}$ Department of Neonatology, Charité - Campus Virchow-Klinikum, Berlin, ${ }^{b}$ Department of \\ Pediatric Endocrinology, Endokrinologikum Hamburg, and ${ }^{\mathrm{C}}$ Department of Pediatrics, University Hospital \\ Hamburg-Eppendorf, Hamburg, Germany
}

\section{Key Words}

Immunofunctional assay · Cut-off level · Growth hormone

determination $\cdot \mathrm{GH}$ peak level $\cdot$ Conversion factor

\begin{abstract}
Conventional assays for determination of growth hormone $(\mathrm{GH})$ in serum measure immunoreactive molecules of a blood sample. The immunofunctional assay (IFA), on the other hand, is able to determine biologically active molecules. In our study, we evaluated GH determination in children with IFA to compare these data with clinical reliable data of conventional assay systems, since there is only insufficient data concerning the clinical use of IFA in children. The comparison of GH determinations by IFA and two immunoradiometric assays showed different results for the same serum sample. Peak and trough concentration levels determined by these three different assays were always measured at the same time, but absolute GH concentration levels varied. Statistic analysis verified a linear regression of our data and allowed a conversion of data measured by IFA to predict values of the other assays used and vice versa. The traditional cut-off level for the diagnosis of GH deficiency of 10 $\mathrm{ng} / \mathrm{ml}$ was based originally on results of polyclonal radioimmunoassays. This internationally applied cut-off level has
\end{abstract}

been converted based on the regression analysis for prediction of this study and we found the $95 \%$ confidence interval on the mean measurements by IFA to be between 3.11 and $3.28 \mathrm{ng} / \mathrm{ml}$.

Copyright $\odot 2007$ S. Karger AG, Basel

\section{Introduction}

The diagnosis of growth hormone (GH) deficiency or acromegaly in children is based on clinical-auxological criteria and NMR imaging of the pituitary gland [1]; it is, however, confirmed through a determination of GH concentration in serum during pharmacological provocation tests. The result of these measurements effects the finding of the diagnosis greatly and is the decisive criteria for therapy [2], although the final decision for therapy is made by a pediatric endocrinologist. Cut-off levels were established empirically for the diagnosis of GH deficiency at $10 \mathrm{ng} / \mathrm{ml}$ [2] during stimulation tests. For acromegaly, the cut-off level needs to be suppressed below $1 \mathrm{ng} / \mathrm{ml}$ [3] during the glucose tolerance test.

Even though commercially available assay kits are calibrated against the GH international reference preparations, it has been illustrated in many studies that results

\section{KARGER}

Fax +4161306 1234 E-Mail karger@karger.ch www.karger.com

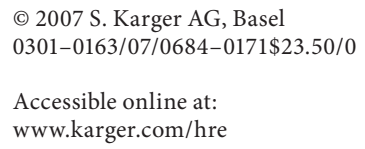

Department of Neonatology, Charité - Campus Virchow Klinikum

University Medical Center, Augustenburger Platz 1

DE-13353 Berlin (Germany)

Tel. +49 3044938 440, Fax +4930 44038 455, E-Mail simone.stark@charite.de 
Table 1. Clinical features of the patients

\begin{tabular}{lll}
\hline & Short stature & Tall stature \\
\hline Number & 98 & 6 \\
Female/male & $45 / 53$ & $4 / 2$ \\
Age, years & $10.9 \pm 3.3(3.2$ to 17.3$)$ & $10.9 \pm 4.5(3.7$ to 16.8$)$ \\
Height, SDS & $-2.8 \pm 1(-5.91$ to -0.02$)$ & $3.05 \pm 0.61(1.88$ to 3.53$)$ \\
IGF-I, SDS & $-0.83 \pm 0.92(-2.33$ to 4.93$)$ & $1.81 \pm 1.89(-0.59$ to 4.10$)$ \\
IGFBP-3, SDS & $0.11 \pm 1.47(-2.95$ to 10.31$)$ & $1.97 \pm 0.79(0.65$ to 2.62$)$ \\
\hline
\end{tabular}

between laboratories and when using different immunoassays varied [4-8]. Stahnke and Jenke [9] entitled the finding as 'comparing apples with pears'. So far, there is no uniform assay system for determination of GH in serum. Therefore, it is very important to standardize the assays independent of their characteristics.

When determining $\mathrm{GH}$ concentration in a serum sample, it is important to find the amount of biologically active molecules in the circulation at the time of withdrawal [10]. The conventionally applied immunoassays do not answer this question, since they measure the total amount of immunoreactive GH molecules in serum including all of their variants, fragments and aggregations [11], dependent on the epitope specificity of the used antibody [12]. The immunofunctional assay (IFA) method developed by Strasburger et al. [10] is able to determine biologically active GH molecules. IFA uses first a monoclonal antibody and recombinant $\mathrm{GH}$-binding protein (GHBP) as the second binding agent, they both bind on the two sides of the GH molecule where the receptor interaction is usually performed.

So far, there is no data concerning GH determination by IFA in children that can be applied in clinical practice; this method is thus approved only in a research setting. Therefore, in this study we evaluated the IFA in comparison to conventional immunoradiometric assays (IRMA) for $\mathrm{GH}$ determination in children.

\section{Methods and Materials}

The Immunofunctional Assay

Strasburger et al. [10] developed an innovative determination method for $\mathrm{GH}$, that uses the physiologic hormone-receptor binding of GH to measure only the biologically active molecules [10]. To initiate a biological signal in target cells the GH molecule requires an interaction of the two receptor binding sites with the $\mathrm{GH}$ receptor dimer at the cell surface [13]. The GH molecule interacts with the receptor molecule dimer through binding site one with a large contact surface area involving 31 amino acid sidechains and via binding site two of GH with a smaller surface [14].
Based on this process, Strasburger et al. [10] designed a sandwich immunoassay that uses first a monoclonal antibody overlapping largely with binding site two, which is bound to the microtiter plates. The biotinylated recombinant GHBP is the second binding agent, that is identical with the ectodomain of the GH-receptor and binds to the binding site one of the GH molecules. Europiumlabeled streptavidin is then used to link with the detector reagent. Therefore, only those GH molecules are measured that possess these two intact binding sites mentioned previously and are potentially biologically active. Correlation with the $\mathrm{Nb} 2$ bioassay showed a good correlation $\left(r^{2}=97 \%\right)$, which confirms a successful determination of the biological activity with IFA [10].

The IFA is calibrated against the first International Standard (IS) for somatropin (STH) 88/624, which is identical with recombinant hGH. The cross-reactivity of the $22-\mathrm{kDA}$ recombinant hGH with pituitary 22- and $20-\mathrm{kDa}$ was 53.3 and $45.7 \%$, respectively. As IFA utilizes recombinant GHBP for detection, the specificity is presumed to be greater on the basis of a larger recognition site with a sequence of 31 amino acids compared to a recognition sequence of approximately 10 amino acids of monoclonal antibodies [10].

\section{Study Subjects}

Serial sera of 104 children with growth disorders, aged 3-17 years, have been analyzed (table 1). For each subject, GH has been measured in sequential sera-samples during GH-stimulation or -suppression tests.

\section{Study Design}

Stimulation (provocation) tests were applied depending on age and health of children tested: physical exercise tests $(n=81)$, insulin-induced hypoglycemia tests $(n=13)$, arginine tests $(n=17)$, glucagon tests $(n=4)$, GHRH tests $(n=2)$, oral glucose tolerance tests $(\mathrm{n}=11)$ and profiles of spontaneous secretion of GH overnight $(\mathrm{n}=5)$.

GH was measured by IFA (ACTIVE ${ }^{\mathrm{TM}}$ IFHGH, Diagnostic System Laboratories, Sinsheim, Germany), the Biochem SERIA assay termed MIA (SERIA hGH, Biochem Immunosystems $\mathrm{GmbH}$, Freiburg, Germany) and the Schering RIACT assay termed RIA (hGH-RIACT, Schering CIS bio international, Berlin, Germany). MIA and RIA are both two-step sandwich IRMA systems for GH determination. Each assay uses two monoclonal antibodies binding to different epitopes of the GH molecule, one antibody is radioactively labeled (iodine 125), while the other antibody is used for separation. The standards of the MIA and the RIA assay systems were calibrated against the first IS for hGH 


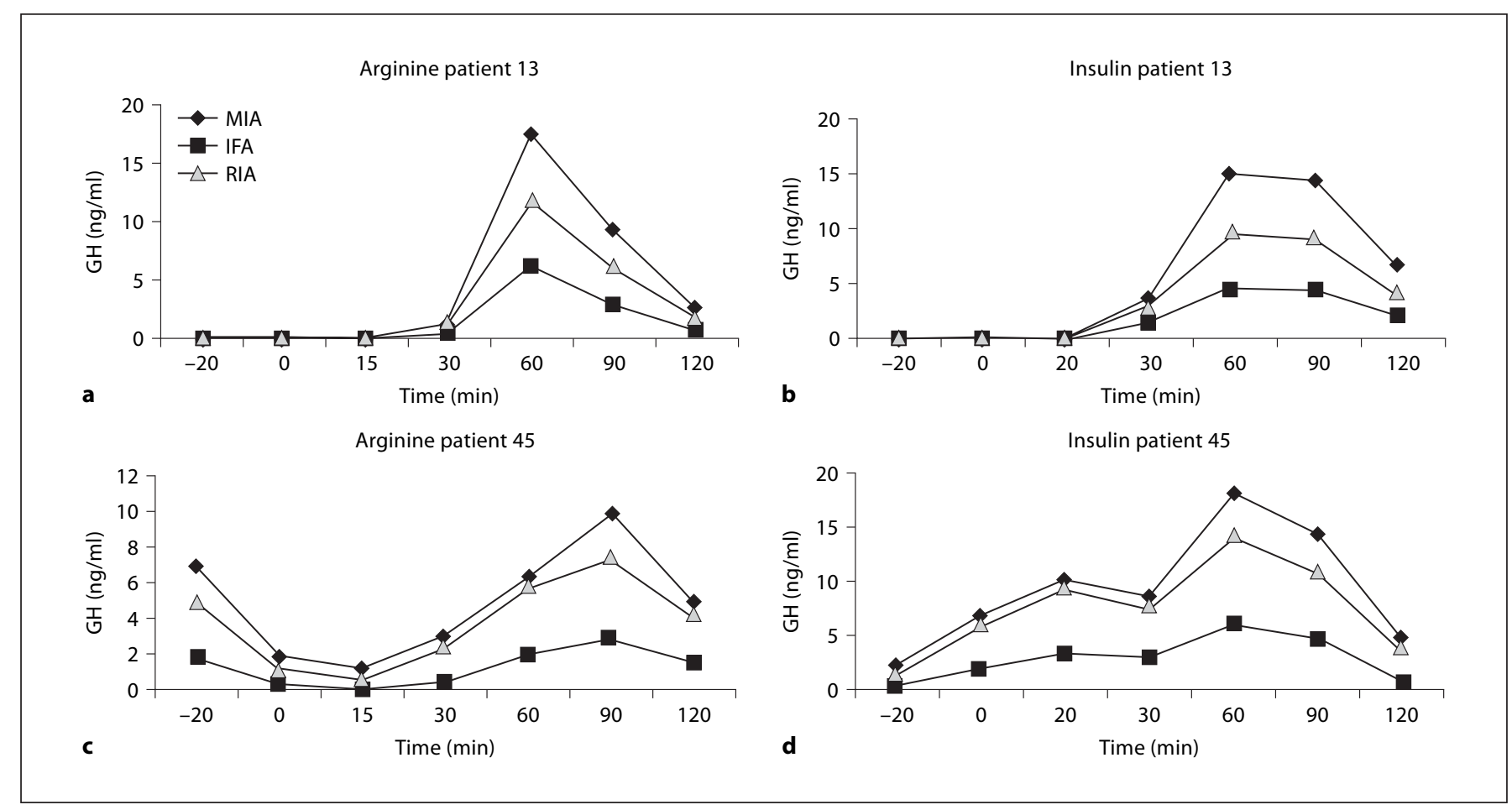

Fig. 1. GH concentrations determined by MIA, IFA and RIA of two patients during stimulation tests with arginine or insulin at $-20,0,15,20,30,60,90$ and $120 \mathrm{~min}$. Patient 13 during stimulation test with arginine (a) or with insulin (b). Patient 45 during stimulation test with arginine (c) or with insulin (d).

80/505. For MIA the lower detection limit (sensitivity), as defined by the mean \pm 2 standard deviations of a 20 -fold zero standard determination, is $0.1 \mathrm{ng} / \mathrm{ml}$ with an intra- and interassay coefficient of variation (CV) of $1.0-1.4 \%$ and $3.2-4.1 \%$. The sensitivity of RIA is $0.02 \mathrm{ng} / \mathrm{ml}$ with an intra- and interassay CV of $1.3-2.1 \%$ and $3.8-5.0 \%$. For MIA a cut-off level for GH deficiency at $10 \mathrm{ng} /$ $\mathrm{ml}$, for acromegaly at $1 \mathrm{ng} / \mathrm{ml}$ is applied and the assay results were evaluated each year by an organized interlaboratory survey by order of the Federal Medical Association of Germany (Deutsche Bundesärztekammer).

132 of the 133 stimulation tests were measured by both IFA und MIA, 7 stimulation tests were determined by both IFA and RIA and 6 stimulation tests were measured by all three assays.

The concentrations of insulin-like growth factor-I (IGF-I) and IGF-binding protein-3 (IGFBP-3) were measured using radioimmunoassays by Mediagnost (Reutlingen, Germany) according to the protocol supplied by the manufacturer.

\section{Statistical Analysis}

The measurements of the different assays were analyzed by conventional methods of descriptive and analytical statistics such as correlation, correlation coefficient, regression, regression coefficient, area under the curve and confidence interval to estimate the relative associations between the results of the GH assays. Significance was established at $\mathrm{p}<0.05$. The program Microsoft Excel and the statistic program XLStatistics [15] were used.

\section{Results}

The precision of IFA was good with an intraassay CV of $2.8-3.3 \%$ and an interassay $\mathrm{CV}$ of $4-8 \%$, respectively. The sensitivity was excellent with $0.09 \mathrm{ng} / \mathrm{ml}$.

All assays were easy to perform and required only small amounts of serum ( $50 \mu \mathrm{l}$ for IFA and RIA, $100 \mu \mathrm{l}$ for MIA). The enzymatic-working IFA had no safety precautions to comply, as no radioactivity was used.

The comparison of GH determinations by the three assays showed different results for the same serum sample (fig. 1a-d). Each patient demonstrates a characteristic $\mathrm{GH}$ concentration curve during provocation tests with peak and trough levels, that is similar when measured by all three assays, but on varying absolute GH concentration levels.

The association between GH measurements determined by the three different assays was studied by regression analysis. As data of RIA were limited, the main analysis was performed with data of IFA and MIA.

Comparing the data determined by IFA to the data determined by MIA showed very strong linear correlations for independent data values, for the correlation of 


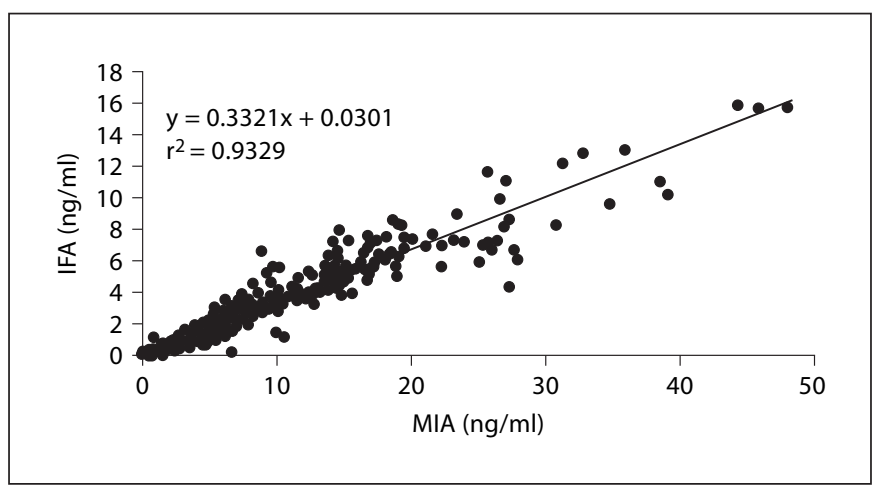

Fig. 2. Diagram of all determined GH concentrations by MIA and IFA, the regression shows a very strong correlation with a high correlation coefficient $\mathrm{r}=0.966$.

areas under the GH concentration curves $(r=0.97)$ including data of all stimulation tests and for the correlation of peak GH concentrations $(r=0.96)$ including data of all stimulation tests. The correlation coefficient (r) of each single stimulation test regression was in the range from $r=0.93$ to 0.99 . Comparing the splitting of these data in short- and tall-statured children showed no significant differences. As these analytic results for independent measurements showed correlation coefficients of nearly 1 , the linear association between IFA and MIA is presumptive. Therefore, the complete dataset was used for further regression analysis.

The correlation of the complete dataset determined by IFA versus MIA (fig. 2), IFA versus RIA (fig. 3) and RIA versus MIA (not shown) demonstrate also a strong linear association with high correlation coefficients $\left(\mathrm{r}_{\text {IFA to MIA }}=0.97 ; \mathrm{r}_{\text {IFA to RIA }}=0.996 ; \mathrm{r}_{\text {RIA to MIA }}=0.96\right)$.

When splitting the results measured by IFA versus MIA in unstimulated and stimulated GH measurements, the difference of the regression analysis was significant. The confidence interval of the slope of unstimulated samples was $2.43-2.53$ and of stimulated samples was 2.89-3.08, they did not overlap. Dividing the complete dataset of MIA and IFA into short- and tall-statured children resulted in no significant difference.

Regression analysis indicated a linear association between MIA and IFA. Therefore, it was possible to convert the data of MIA into predicted data of IFA and vice versa. It is not a single value, but a confidence interval that includes the true value with $95 \%$ probability. As the results of linear regression analysis of unstimulated and stimulated samples differed significantly, the conversion of the data had to be split. The conversion factor from IFA to

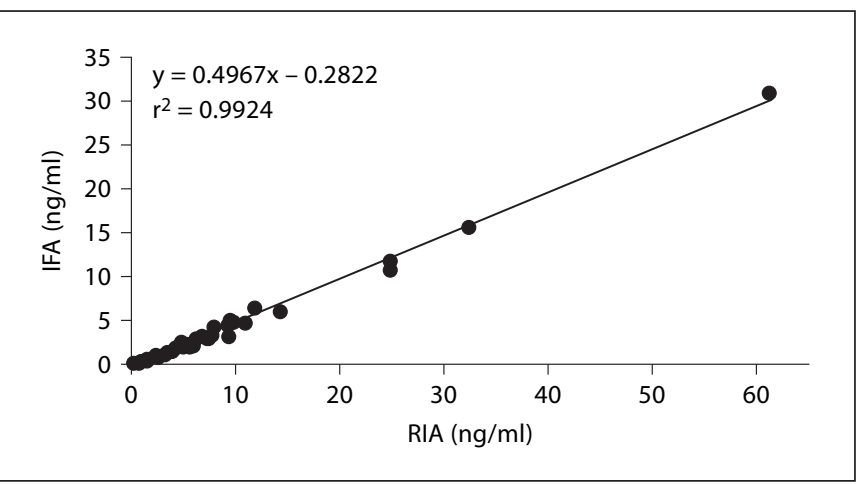

Fig. 3. Diagram of all determined GH concentrations by RIA and IFA, the regression shows a very strong correlation with a high correlation coefficient $r=0.996$

MIA for unstimulated samples is between 2.43 and 2.53 and for stimulated samples between 2.89 and 3.08. It is also possible to predict $95 \%$ confidence intervals on mean single GH measurement of one assay for a given single $\mathrm{GH}$ measurement of the other assay. For the important cut-off level for GH deficiency of $10 \mathrm{ng} / \mathrm{ml}$ determined by MIA, we found the $95 \%$ confidence interval on the mean measurements by IFA to be between 3.11 and $3.28 \mathrm{ng} / \mathrm{ml}$ for stimulated samples, the 'IFA cut-off level'.

For the cut-off level for acromegaly during the glucose tolerance test of $1 \mathrm{ng} / \mathrm{ml}$ determined by MIA, we found the $95 \%$ confidence interval on the mean measurements by IFA to be between 0.26 and $1.05 \mathrm{ng} / \mathrm{ml}$ for stimulated samples.

Regression analysis between the peak level concentration of GH determined by MIA or IFA and the concentration of IGF-I and IGFBP-3 in each patient showed no significant statistic association ( $\mathrm{r}_{\text {IGF-I }}$ to MIA $=0.20 ; \mathrm{r}_{\text {IGF-I }}$ to IFA $=0.24 ; \mathrm{r}_{\mathrm{IGFBP}-3}$ to MIA $=0.04 ; \mathrm{r}_{\mathrm{IGFBP}-3}$ to IFA $\left.=0.07\right)$.

\section{Discussion}

The standardization of GH measurements is an important and demanding goal in clinical practice for easy comparability of test results. In this study, we demonstrate that the results of GH measurements depend on the assay used for determination. Thus, our results are in line with previous reports that have shown poor agreement of assays for GH determination [4-9]. The determination of GH during stimulation test in children was performed with the IFA method in comparison to two IRMAs (MIA and RIA) to evaluate clinical data measured by IFA in 
children and thereby to achieve a cut-off level for GH determination by IFA in children.

Each patient has an own characteristic GH concentration curve during stimulation tests that is comparable between GH measurement assays; however, the results of single concentration levels vary between assays (fig. 1ad). Peak and trough levels of concentration were measured at the same time and in the same serum sample in all three assays. For example, the GH peak level for patient 45 at $60 \mathrm{~min}$ during an arginine test was $2.9 \mathrm{ng} / \mathrm{ml}$ when using IFA, $10.1 \mathrm{ng} / \mathrm{ml}$ with MIA and $7.4 \mathrm{ng} / \mathrm{ml}$ when applying RIA. Thus, the applied assay system influences the decision whether this child has a GH deficiency or not dramatically when adopting the empiric cut-off level of $10 \mathrm{ng} / \mathrm{ml}$. It is therefore important to know the difference between the results of various assay systems.

The three assay systems compared in this study demonstrate very different quantitative $\mathrm{GH}$ concentration levels, but the results correlated well with each other $[16$, 17]. The linear regression between MIA and IFA was demonstrated graphically (fig. 2) and statistically, independent of the stimulation test used. The separation in unstimulated and stimulated samples demonstrated a significant difference with a conversion factor from IFA to MIA of approximately 2.5 for unstimulated and of approximately 3 for stimulated values. The cause for this observation is not clear. One reason could be that the relative proportion of different molecular forms of $\mathrm{GH}$ changes in the circulation with time following secretion during stimulation test $[11,18,19]$. The clearance of the molecules differs; after a secretory event GH associates quickly with circulating binding proteins and other $\mathrm{GH}$ variants to form dimers or oligomers, which are cleared more slowly than monomers. Therefore, it is possible that a binding site for an antibody is masked. Wood [19] proposed that a comparison on unstimulated or fasting samples may not be valid after a secretory event since relative assay biases may change with time following GH secretion. This could be one of the advantages of IFA in comparison to MIA and other radioimmunoassays. In the phase of stimulation, secretion consists presumptively more of molecules that are not biologically active, i.e., they do not have the two binding sites IFA requires for $\mathrm{GH}$ measurement. These could be fragments or posttranslationally modified $\mathrm{GH}$ forms or other molecules variants. The relative relation of 20 - to $22-\mathrm{kDa}$ isoforms of GH should not be the reason, as it is supposed to not change after secretion $[20,21]$.

Baumann [18] assumed that there is a significant contribution of immunoreactive fragments of $\mathrm{GH}$ to the overall GH immunoreactivity in plasma, particularly relevant in the unstimulated samples with relatively low absolute GH concentration. This assumption is in contrast to the finding in our study, as the ratio of immunoreactivity over bioactivity (MIA over IFA) was found to be higher in the stimulated than in the unstimulated samples. A further reason could be the interference of endogenous GHBP with antibody binding of GH. IFA commercially available from DSL is not supplied with a solution that contains an excess of labeled GHBP over the maximum level of endogenous GHBP occurring in serum (as in the original IFA of Strasburger) and is therefore influenced by physiological amounts of endogenous GHBP in serum [5]. After stimulation of GH secretion GHBP levels may also increase; the influence of GHBP through GH is, however, controversial [22] and the ratio of endogenous to exogenous (labeled) GHBP varies to such an extent that there is a significant difference in the GH measurement results of unstimulated and stimulated samples. This point needs to be addressed in further studies.

We detected very low peak GH concentrations with IFA, one of the newer generation GH assays that uses IS $88 / 624$ for calibration, so that the conventional cut-off level of $10 \mathrm{ng} / \mathrm{ml}$ could not be applied. This result is in line with results of recently published papers $[23,24]$.

In the present study, multiple linear regressions demonstrated high correlation coefficients, and it was possible to ascertain conversion factors between MIA and IFA. We found a new cut-off level for GH deficiency determined by IFA between 3.11 and 3.28 for stimulated samples.

In another study, Chaler et al. [25] investigated one single GH determination assay using different standards for calibration (IS 66/216, 80/505 und 88/624) to evaluate the proposed cut-off level of $10 \mathrm{ng} / \mathrm{ml}$. When calibrating against IS 88/624 they found a cut-off level of $4.39 \mathrm{ng} / \mathrm{ml}$ and thus a conversion factor of 2.28 , which is different to the one in our study that is specific for the IFA method. This demonstrates that the absolute difference in GH determination is probably based on the varying standards for the most part. Hence, it is not possible to designate one single cause for the lower measurement results, but the influencing factors seem to be stable as the linear correlation is high.

Silva et al. [26] have defined a cut-off level of $3.3 \mathrm{ng} / \mathrm{ml}$ with a new immunofluorometric assay of children with short and normal stature. In another study, they found a cut-off level between 2 and $4 \mathrm{ng} / \mathrm{ml}$ for assays of the new generation [27]. These were close to the converted results of this study. 
For acromegaly, we found a new cut-off level determined by IFA between 0.26 and $1.05 \mathrm{ng} / \mathrm{ml}$ for stimulated samples. As the new assays are supposed to be more sensitive, the tendency to lower cut-off levels was anticipated and the estimation of less than $0.3 \mathrm{ng} / \mathrm{ml}$ [28] confirms the range of this study.

There were no correlations between the peak of stimulated GH measured by IFA or by MIA and the IGF-I and IGFBP-3 concentrations, as described before $[24,29]$. It may be that the free IGF-I produced in the tissue has to be measured, which is supposed to be the correct biologically active proportion [30,31].

Wood [19] compared serum GH measurement by the IFA and a two-site immunometric assay calibrated against IS 80/505 (Immunlite Asalyzer DPC Ltd., Glyn Rhonwy, UK). When peak GH responses were compared, the IFA results were on average $42.5 \%$ of the immunometric assay results, which corresponds to a relation of 1 to 2.35. In 20 stimulation tests they identified a delayed IFA peak in five series (25\%) and an advanced peak in one series (5\%) relative to the conventional immunometric assay. A reason for this dissimilarity has not been found.

Another investigation by Hauffa et al. [23] applied the IFA method and other different assay systems for $\mathrm{GH}$ measurement to determine only maximum serum concentrations identified by local assays that were sent for interlaboratory comparison. The best correlation was found to be $r=0.86$. They described slopes of regression lines from 1.28 and 1.65. Significant non-linearity was detected in five of six assay comparisons, indicating that most assays results cannot be converted by the use of a factor. They did not find advanced or delayed peak levels like those mentioned by Wood [19] and explained the dissimilarity with the fact of only having measured maximum serum concentrations which could prevent these occurrences of peak deviations [23].

In the present study, the peak levels were consistently parallel in each of the three assays to the same time, and no delayed or advanced peaks were detected in any of the 133 provocation tests that have been applied (fig. 1a-d).

\section{Conclusion}

As the bias of GH measurements of various assay systems and in between laboratories is well known, comparison of results are not useful. Factors influencing the determination of GH in serum such as, e.g., the use of different standard preparations, the heterogeneity of the $\mathrm{GH}$ molecules in serum, various epitope specificity of the antibodies, influence by endogenous GHBP, matrix effects by serum additions, varying cut off-levels with differing interpretations and various biological activity of several GH isoforms have been identified. Even though there have been many approaches to uniform some of the influencing factors there is still no improvement for a convenient comparison of $\mathrm{GH}$ measurement.

The innovative IFA investigated in this study should be renewed concerning the influence of endogenous GHBP [5]. Apart from this problem it may present a valid replacement for the conventional GH assays, since its sensitivity and precision for physiological GH concentrations is excellent, it is calibrated against the recommended IS $88 / 624$, its measurement is enzymatic without radioactivity and the antibody combination used (especially the recombinant GHBP) is specific for biologically active molecules. Specific cut-off levels were investigated in the present study.

Thus, the IFA is an advisable assay for GH determination in clinical routine use. It will, however, not solve the problem of poor agreement of the results of GH measurements between the different assay systems and laboratories.

\section{Acknowledgements}

The authors thank Liane Salchow as well as the staff of the central laboratory of the University Hospital Eppendorf of Hamburg, Germany, for their laboratory assistance. The authors are also grateful to all the children and their families that gave consent to use their serum sample(s).

\section{References}

1 Society GR: Consensus guidelines for the diagnosis and treatment of growth hormone (gh) deficiency in childhood and adolescence: summary statement of the gh research society. J Clin Endocrinol Metab 2000;85: 3990-3993.

2 Willig R: Diagnostic and therapy in short stature. Der Kinderarzt 1995;26:995-996.
3 Thorner MO, Vance ML, Laws ERJ, Horvath E, Kovacs K: The anterior pituitary; in Wilson JD, Foster DW, Kronenberg HM, Larsen PR (eds): Williams Textbook of Endocrinology. Philadelphia-Tokyo, Saunders Company, 1998, pp 221-310. 
-4 Andersson AM, Orskov H, Ranke MB, Shalet S, Skakkebaek NE: Interpretation of growth hormone provocative tests: comparison of cut-off values in four european laboratories. Eur J Endocrinol 1995;132:340343.

$>5$ Ebdrup L, Fisker S, Sorensen HH, Ranke $\mathrm{MB}$, Orskov $\mathrm{H}$ : Variety in growth hormone determinations due to use of different immunoassays and to the interference of growth hormone-binding protein. Horm Res 1999;51(suppl 1):20-26.

6 Jansson C, Boguszewski C, Rosberg S, Carlsson L, Albertsson-Wikland K: Growth hormone (gh) assays: Influence of standard preparations, gh isoforms, assay characteristics, and gh-binding protein. Clin Chem 1997;43:950-956.

7 Preece MA: Making a rational diagnosis of growth-hormone deficiency. J Pediatr 1997; 131:S61-S64.

8 Rosenfeld RG, Albertsson-Wikland K, Cassorla F, Frasier SD, Hasegawa Y, Hintz RL, Lafranchi S, Lippe B, Loriaux L, Melmed S, et al: Diagnostic controversy: the diagnosis of childhood growth hormone deficiency revisited. J Clin Endocrinol Metab 1995;80: 1532-1540.

9 Stahnke N, Jenke I: Compairing apples with pears. Pediatr Res 1993;33(suppl 5):386.

-10 Strasburger CJ, Wu Z, Pflaum CD, Dressendorfer RA: Immunofunctional assay of human growth hormone (hgh) in serum: a possible consensus for quantitative hgh measurement. J Clin Endocrinol Metab 1996;81: 2613-2620.

11 Baumann G: Growth hormone heterogeneity: genes, isohormones, variants, and binding proteins. Endocr Rev 1991;12:424-449.

12 Strasburger CJ: Antigenic epitope mapping of the human growth hormone molecule: a strategy to standardize growth hormone immunoassays. Acta Paediatr Scand Suppl 1990;370:82-86.
13 Gent J, van Kerkhof P, Roza M, Bu G, Strous GJ: Ligand-independent growth hormone receptor dimerization occurs in the endoplasmic reticulum and is required for ubiquitin system-dependent endocytosis. Proc Natl Acad Sci USA 2002;99:9858-9863.

14 Cunningham BC, Ultsch M, De Vos AM, Mulkerrin MG, Clauser KR, Wells JA: Dimerization of the extracellular domain of the human growth hormone receptor by a single hormone molecule. Science 1991;254:821825.

15 Carr R: Xlstatistics 5.0 xlent works. Australia, 2000.

16 Celniker AC, Chen AB, Wert RM Jr, Sherman BM: Variability in the quantitation of circulating growth hormone using commercial immunoassays. J Clin Endocrinol Metab 1989;68:469-476.

17 Levin PA, Chalew SA, Martin L, Kowarski AA: Comparison of assays for growth hormone using monoclonal or polyclonal antibodies for diagnosis of growth disorders. J Lab Clin Med 1987;109:85-88.

18 Baumann G: Growth hormone heterogeneity in human pituitary and plasma. Horm Res 1999;51(suppl 1):2-6.

19 Wood P: Growth hormone: its measurement and the need for assay harmonization. Ann Clin Biochem 2001;38:471-482.

20 Pringle P, Mellado M, Rodriguez-Frade JM, Achermann J, Massoud AF, Robinson ICAF, Hindmarsh PC: The Measurement of 20k Variant of Human Growth Hormone in $\mathrm{Hu}$ man Serum. New Orleans La., 80th Meeting of the Endocrine Society, 1998, pp 291.

21 Tsushima T, Katoh Y, Miyachi Y, Chihara K, Teramoto A, Irie M, Hashimoto Y: Serum concentration of $20 \mathrm{k}$ human growth hormone (20k hgh) measured by a specific enzyme-linked immunosorbent assay. Study group of 20k hgh. J Clin Endocrinol Metab 1999;84:317-322.

22 Casanueva FF: Physiology of growth hormone secretion and action. Endocrinol Metab Clin North Am 1992;21:483-517.

-23 Hauffa BP, Lehmann N, Bettendorf M, Mehls O, Dorr HG, Partsch CJ, Schwarz HP, Stahnke N, Steinkamp H, Said E, Sander S, Ranke $\mathrm{MB}$ : Central reassessment of gh concentrations measured at local treatment centers in children with impaired growth: Consequences for patient management. Eur J Endocrinol 2004;150:291-297.
24 Mauras N, Walton P, Nicar M, Welch S, Rogol AD: Growth hormone stimulation testing in both short and normal statured children: use of an immunofunctional assay. Pediatr Res 2000;48:614-618.

25 Chaler E, Belgorosky A, Maceiras M, Mendioroz M, Rivarola MA: Between-assay differences in serum growth hormone (gh) measurements: importance in the diagnosis of gh deficiency in childhood. Clin Chem 2001;47:1735-1738.

26 Silva EG, Slhessarenko N, Arnhold IJ, Batista MC, Estefan V, Osorio MG, Marui S, Mendonca BB: Gh values after clonidine stimulation measured by immunofluorometric assay in normal prepubertal children and gh-deficient patients. Horm Res 2003;59: 229-233.

27 Carel JC, Ecosse E, Nicolino M, Tauber M, Leger J, Cabrol S, Bastie-Sigeac I, Chaussain JL, Coste J: Adult height after long term treatment with recombinant growth hormone for idiopathic isolated growth hormone deficiency: observational follow up study of the French population based registry. BMJ 2002;325:70.

28 Trainer PJ: Editorial: Acromegaly - consensus, what consensus? J Clin Endocrinol Metab 2002;87:3534-3536.

29 Juul A, Skakkebaek NE: Prediction of the outcome of growth hormone provocative testing in short children by measurement of serum levels of insulin-like growth factor I and insulin-like growth factor binding protein 3. J Pediatr 1997;130:197-204.

30 Domene HM, Bengolea SV, Martinez AS, Ropelato MG, Pennisi P, Scaglia P, Heinrich JJ, Jasper HG: Deficiency of the circulating insulin-like growth factor system associated with inactivation of the acid-labile subunit gene. N Engl J Med 2004;350:570-577.

31 Le Roith D, Bondy C, Yakar S, Liu JL, Butler A: The somatomedin hypothesis: 2001. Endocr Rev 2001;22:53-74. 